\title{
Genetic variability among genotypes of "gabirobeiras" selected for precocity
}

\author{
Variabilidade genética entre genótipos de gabirobeiras selecionados para \\ precocidade
}

\author{
Eliane Alves dos SANTOS ${ }^{1}$; Edésio Fialho dos REIS²; Jefferson Fernando Naves PINTO³; \\ Danielle Fabíola Pereira da SILVA ${ }^{4}$
}

${ }^{1}$ Graduanda em Ciências Biológicas, Universidade Federal de Goiás / Regional Jataí, elianeje@hotmail.com

${ }^{2}$ Doutor em Genética e Melhoramento Universidade Federal de Goiás / Regional Jataí, edesiofr7@gmail.com

${ }^{3}$ Autor para correspondência, Mestre em Agronomia, Universidade Federal de Goiás / Regional Jataí, jeffnaves@gmail.com

${ }^{4}$ Pós-Doutorado em Fitotecnia, Universidade Federal de Goiás / Regional Jataí, daniellefpsilva@gmail.com

Recebido em: 05-10-2017; Aceito em: 29-01-2018

\begin{abstract}
Gabirobeira is a fruit tree native to the Brazilian Cerrado with a good productivity and acceptance by the local population and with good prospects for processing. Even with the growing interest in the industry and its potential use, information on gabirobas is limited. Therefore, the knowledge of the development, the characteristics of fruits and the genetic divergence is fundamental to define actions of domestication and adaptation to the productive system. The objective of this study is to determine the genetic variability of 173 genotypes of Gabirobeira from the Jataí-Goiás germplasm collection based on plant and fruit morphological traits. The evaluations were carried out in two periods, and eleven morphological traits were evaluated. Based on data, we performed statistical descriptive analysis, correlation analysis, estimation of relative importance of traits and cluster analysis using multivariate techniques (Tocher and UPGMA). The results showed variability and, among the genotypes studied, it was verified that the lowest and the highest CV (15.8\% and 102.49\%) were observed for fruit width and number of branches. The mean values obtained for soluble solids ranged from 6 to $26{ }^{\circ}$ Brix. The contribution of different traits assessed for variability ranged from 0.10 to $27.55 \%$. The dissimilarity varied from 3.64 to 80.35 , with an average of 23.083. Both grouping methods formed 18 groups. These results show that the germplasm collection presents variability, which can be used as a guide for its maintenance with the possibility of exploring this variability in future genetic improvement works.
\end{abstract}

Additional keywords: Campomanesia; germplasm; multivariate techniques.

\section{Resumo}

A gabirobeira é uma fruteira nativa do Cerrado Brasileiro, com boa produtividade e aceitação pela população local e com boas perspectivas para processamento. Mesmo com o crescente interesse da indústria e seu potencial uso, as informações sobre as gabirobeiras são limitadas. Por isso, o conhecimento do desenvolvimento, das características dos frutos e da divergência genética é fundamental para definir ações de domesticação e adequação ao sistema produtivo. Neste estudo, objetivou-se determinar a variabilidade genética de 173 genótipos de gabirobeira da coleção de germoplasma de Jataí-Goiás, com base em caracteres morfológicos da planta e dos frutos. As avaliações foram realizadas em duas épocas e foram avaliados onze caracteres morfológicos. Com base nos dados, realizaram-se a análise estatística descritiva, correlação, estimação da importância relativa dos caracteres e análise de agrupamento, por meio de técnicas multivariadas (Tocher e UPGMA). Os resultados evidenciam existência de variabilidade e, entre os genótipos em estudo, verificou-se que o menor e o maior CV $(15,8 \%, 102,49 \%)$ foram observados para a largura do fruto e o número de ramificações. Os valores médios obtidos de sólidos solúveis variaram de 6 a $26{ }^{\circ}$ Brix. A contribuição de diferentes caracteres avaliados para a variabilidade variou de 0,10 a 27,55\%. Já a dissimilaridade variou de 3,64 a 80,35 , com médias de 23,083 . Ambos os métodos de agrupamento formaram 18 grupos. Estes resultados demonstram que a coleção de germoplasma apresenta variabilidade, a qual pode ser utilizada como um direcionamento para a sua manutenção e com possibilidade de explorar esta variabilidade em futuro trabalho de melhoramento genético.

Palavras-chave adicionais: Campomanesia; germoplasma; técnicas multivariadas. 


\section{Introduction}

The Brazilian Cerrado is a source of reserve of biological resources that presents an economic potential and a large number of fruit species (Coutinho et al., 2010), among which the genus Campomanesia is worth mentioning because it has the potential for commercial exploitation (Freitas et al., 2008).

The genus Campomanesia is popularly known as Gabiroba (Amaral et al., 2016). This genus may be found in field and typical Cerrado landscapes (Coutinho et al., 2010) distributed in the Center-West and Southeast regions of Brazil (Lorenzi et al., 2006).

Its exploitation is extractive, performed in an inadequate way (Pereira et al. 2017). Its use by the industry is incipient (Freitas et al., 2008), but its fruits can be used for consumption in natura, production of sweets (jellies, pans, puddings, sorbets), juices, liqueurs and wine (Pavan et al., 2009).

Gabiroba has good commercial prospects due to a precocity of fruiting, long fruiting period, expressive genetic variability and high market acceptance (Vieira et al., 2006). However, according to Clement (2001), it is considered wild because it is still managed in an extractive way.

Even with the growing interest by the industry for regional products and wild species from Cerrado, information on this species is limited or nonexistent. Therefore, the knowledge of its development, the characteristics of fruits and the genetic variability are fundamental to define management and conservation actions. To estimate the genetic divergence between individuals or populations, biometric models are used usually analyzed by multivariate statistical methods, with multiple information from each evaluation unit expressed in measures of dissimilarities (Sudré et al, 2005).

The information obtained by studies on genetic divergence is used as a subsidy for the conservation and domestication of genotypes in Germplasm Banks, allowing, according to Costa et al. (2011), identifying promising materials to be used in improvement programs.

The objective of this study is to determine the genetic variability of 173 genotypes of Gabirobeira from the Jataí-Goiás germplasm bank regarding plant and fruit morphological traits.

\section{Material and methods}

The genotypes used in this study belong to the "Ex situ" collection of the germplasm bank of the Federal University of Goiás, Jataí Regional, in the municipality of Jataí, GO (17052'53" S, 51\%42'52" W and 696 meters of altitude). The collection consists of genetic material from Campomanesia from 17 municipalities in the state of Goiás. The fruits used to obtain seeds were harvested in October 2009, and the sowing was performed immediately after harvesting (Assis et al., 2013) in a greenhouse. Approximately four months after sowing, transplanting to the field was carried out (Assis et al., 2013).

As soon as plants began the reproductive phase, in August 2013, 46 months after sowing, the flowering and the fruit production were evaluated, at which time such plants were identified for the study schedule. 173 genotypes were used.

The evaluations of the morphological characteristics of plants were carried out in two periods, the first on September 29, 2014 (2014), and the second on June 6, 2015 (2015), with an interval of 8.33 months between evaluations. The evaluation of the characteristics of fruits was carried out from September 29,2014 , to January 29,2015 , comprising the whole period of fruiting.

For the morphological characterization of all 173 genotypes studied, six plant morphological characteristics and five characteristics of fruits were evaluated: height of the plant (HP) from the soil level to the apex of the highest stem in cm (HP-2014 and HP-2015), canopy width at its largest region in $\mathrm{cm}$ (CW-2014 and CW-2015) measured using a tape measure, diameter of the main stem at soil level (DS2014 and DS-2015) measured with a digital caliper in millimeters, number of branches from the plant base at soil level (NB-2014 and NB-2015) counted by direct counting, length of three fully developed leaves (LL-2014 and LL-2015) measured with a digital caliper in millimeters, width of three fully developed leaves (WL-2014 and WL-2015) calibrated with a digital caliper in millimeters, weight of ten fruits in grams (FW) using a semi-analytic balance, average number of seeds in ten fruits (NS) counted by direct counting, mean diameter of ten fruits (DF) measured with a digital caliper in millimeters, average length of ten fruits (LF) measured with a digital caliper in millimeters, and soluble solids content by refractometry in ten fruits per plant and results expressed in ${ }^{\circ}$ Brix. Based on the data obtained for the 11 characteristics evaluated, a Pearson's correlation analysis and an estimation of the relative importance of the traits in the differentiation of the individuals were performed by the statistical method of Singh (1981).

In order to quantify the genetic divergence among the 173 genotypes studied, a multivariate analysis was performed to evaluate genetic divergence, estimating the mean Euclidean distance between the studied genotypes. Based on the average Euclidean distance, the genotypes were grouped by the Tocher method.

The grouping of genotypes was made using the UPGMA method and the mean Euclidean distance matrix (Cruz et al., 2011). The cut-off point at each stage of the grouping in the dendrogram (UPGMA) was established according to the method of Mojena (1977) using the value of $k=1.25$ as a stop rule in the definition of number of groups according to Milligan \& Cooper (1985). All analyses were performed using the GENES software (Cruz, 2016), and the dendrogram was plotted using the software Statsoft (Statsoft inc., 1999). 


\section{Results and discussion}

The results show the existence of variability, which can be quantified by the magnitudes of the coefficients of variation, since it is a statistical measurement that allows evaluating data homogeneity. Table 1 shows a lower CV (15.8\%) for fruit width and a higher CV for number of branches (102.49\%). It is observed that some characteristics have a greater uniformity than others do, which can be used in a domestication and improvement program because they present better data homogeneity and less chance variation (Garcia, 1989, Lima et al., 2004). Another important information is the amplitude of variation (difference between maximum values and minimum values), where expressive amplitudes are verified for several traits.

Table 1 - Minimum values, maximums and estimates of the mean, coefficient of variation (CV\%), standard deviation (SD) and relative contribution by Singh method (S.j\%).

\begin{tabular}{lrrrrrr}
\hline Variável $^{(1)}$ & Minimum & Mean & Maximum & CV & SD & S.j (\%) \\
\hline HP-2014 $(\mathrm{cm})$ & 9.50 & 71.02 & 154 & 38.49 & 27.34 & 13.70 \\
HP-2015 $(\mathrm{cm})$ & 26.00 & 82.03 & 210 & 35.14 & 28.82 & 15.22 \\
CW-2014 $(\mathrm{cm})$ & 8.00 & 66.37 & 184 & 54.31 & 36.04 & 23.81 \\
CW-2015 $(\mathrm{cm})$ & 13.00 & 86.01 & 238.5 & 45.07 & 38.77 & 27.55 \\
DS-2014 $(\mathrm{mm})$ & 1.16 & 13.67 & 34.94 & 53.31 & 7.28 & 0.97 \\
DS-2015 (mm) & 3.04 & 18.83 & 72.23 & 48.36 & 9.10 & 1.52 \\
NB-2014 & 1 & 3.23 & 18 & 102.49 & 3.31 & 0.20 \\
NB-2015 & 1 & 3.23 & 18 & 102.49 & 3.31 & 0.20 \\
LL-2014 (mm) & 14.6 & 67.77 & 111.36 & 23.22 & 15.73 & 4.54 \\
LL-2015 (mm) & 45.00 & 79.37 & 122.91 & 20.26 & 16.08 & 4.74 \\
WL-2014 (mm) & 6.89 & 25.03 & 51.89 & 30.15 & 7.55 & 1.04 \\
WL-2015 (mm) & 10.33 & 28.43 & 52.02 & 27.28 & 7.75 & 1.10 \\
FW $(\mathrm{g})$ & 0.82 & 2.42 & 7.614 & 47.02 & 1.14 & 2.37 \\
NS & 0.50 & 2.54 & 6 & 46.87 & 1.19 & 2.60 \\
DF $(\mathrm{mm})$ & 9.26 & 15.12 & 23.9 & 16.99 & 2.57 & 0.12 \\
WF $(\mathrm{mm})$ & 9.92 & 15.32 & 23.23 & 15.80 & 2.42 & 0.10 \\
SS & 6 & 15.02 & 26 & 19.35 & 2.90 & 0.15 \\
\hline
\end{tabular}

(1) Height of plant (HP-2014 and HP2015), canopy width (CW-2014 and LC-2015), diameter of stem (DC-2014 and DC-2015), number of branches (NB-2014 and NB-2015), length of leave (LL-2014 and LL-2015), width of leave (WL-2014 and WL-2015), fruit weight (FW), number of seeds (NS), diameter of fruit (DF), width of fruit (WF), and soluble solids (SS)

In relation to fruit-related traits, the coefficient of variation ranged from 15.80 to $47.02 \%$ for fruit weight (WF) and average number of seeds (NS) per fruit, i.e., the traits that presented the highest coefficients of variation, being this result superior to that obtained by Oliveira et al. (2011), who also worked with Gabirobas. Dresch et al. (2013), working with biometric aspects of fruits and seeds of Gabirobeira in Ponta Porã (MS), found a CV variation for fruit characteristics ranging from 4.99 to 16.11 . Fruit weight was the characteristic that presented the highest CV, corroborating with the results found in this study. In contrast, the mean and maximum values for fruit weight, diameter and width were lower than those reported by Oliveira et al. (2011) and Alves et al. (2013), evidencing that the collection under study has a variability for these traits and can thus establish a selective process according to the interest in standardization and generation of a new cultivar.

The mean number of seeds observed in this study was low, ranging from 0.5 to 6 seeds per fruit, considering a sample of 10 fruits. The genus Campomanesia may present a locular ovary, with several ovules per loci (Lima et al., 2011). The species
Campomanesia adamantium has five locules per fruit (Oliveira et al., 2011). The low number of seeds is considered a characteristic trait of the family Myrtaceae (Oliveira et al., 2011) because, during the formation of seeds, there is a decrease in the number of viable ovules, aiming with this the concentration of reserves in the remaining ovules. Then, there is the production of Tupertin (monoterpene - $\mathrm{C}_{10} \mathrm{H}_{16}$ ), which has bad organoleptic characteristics and is deposited on the glandular wall of the inoculum, indicating the preservation of seeds until the moment of dispersion (Landrum, 1982).

The average values for soluble solids for the studied genotypes ranged from 6 to 26, with a CV of $19.35 \%$ (Table 1). These values for soluble solids are higher than results reported by Morzelle et al. (2015). This result is an indication that the studied material has a wide variability for soluble solids, which makes it possible to identify individuals aiming different objectives.

The contribution to variability ranged from $0.10 \%$ to $27.55 \%$. HP-2014, HP-2015, CW-2014 and CW-2015 were the main contributors: $13.70 \%$, $15.22 \%, 23.81 \%$ and $27.55 \%$, respectively (Table 1 ). NB-2014, NB-2015, SS, DF and WL $(0.20 \%, 0.20 \%$, 
$0.15 \%, 0.12 \%$ and $0.10 \%$ ) contributed the least to an increased variability. This result shows that plant morphology has a greater contribution in the variability of the studied material.

The Pearson correlation (Table 2) among the evaluated characteristics showed that there was a positive and significant correlation between $34.55 \%$ of the traits evaluated, and the correlations ranged from 0.15 to 1.00 ; in contrast, there were $13.24 \%$ of negative and significant correlations, ranging from 0.15 to 0.34 .

Table 2 - Pearson correlation coefficients estimates between the morphological descriptors used for 173 Gabiroba accessions

\begin{tabular}{lclllllll}
\hline & HP-2014 & HP-2015 & CW-2014 & CW-2015 & DS-2014 & DS-2015 & DF-2014 & DF-2015 \\
\hline HP-2015 & $0.64^{* *}$ & & & & & & & \\
WC-2014 & $0.66^{* *}$ & $0.47^{* *}$ & & & & & & \\
WC-2015 & $0.51^{* *}$ & $0.73^{* *}$ & $0.58^{* *}$ & & & & & \\
DS-2014 & $0.7^{* *}$ & $0.45^{* *}$ & $0.66^{* *}$ & $0.46^{* *}$ & & & & \\
DS-2015 & $0.39^{* *}$ & $0.41^{* *}$ & $0.34^{* *}$ & $0.49^{* *}$ & $0.60^{* *}$ & & & \\
DF-2014 & $0.19^{*}$ & 0.04 & $0.17^{*}$ & 0.12 & $0.21^{* *}$ & $0.20^{* *}$ & & \\
DF-2015 & 0.07 & 0.05 & 0.04 & 0.06 & 0.14 & $0.23^{* *}$ & $0.53^{* *}$ & \\
WL-2014 & $0.23^{* *}$ & $0.21^{* *}$ & 0.13 & 0.12 & $0.23^{* *}$ & $0.2^{* *}$ & $0.32^{* *}$ & $0.23^{*}$ \\
WL-2015 & $0.16^{*}$ & $0.17^{*}$ & 0.06 & 0.08 & $0.16^{*}$ & $0.16^{*}$ & $0.17^{*}$ & $0.44^{* *}$ \\
NB-2014 & $0.16^{* *}$ & -0.14 & -0.04 & -0.04 & $-0.22^{* *}$ & $-0.34^{* *}$ & -0.10 & -0.08 \\
NB-2015 & $-0.16^{*}$ & -0.14 & -0.04 & -0.04 & $-0.22^{* *}$ & $-0.34^{* *}$ & -0.10 & -0.08 \\
FW & -0.04 & -0.14 & -0.08 & $-0.22^{* *}$ & -0.08 & -0.11 & 0.00 & $0.15^{*}$ \\
SS & 0.02 & 0.11 & 0.07 & $0.21^{* *}$ & 0.13 & $0.19^{*}$ & 0.09 & 0.04 \\
NS & 0.05 & 0.03 & -0.11 & -0.13 & -0.06 & -0.07 & -0.04 & 0.11 \\
DF & -0.05 & -0.11 & -0.10 & $-0.20^{* *}$ & -0.13 & $-0.16^{*}$ & 0.04 & $0.18^{*}$ \\
WF & -0.11 & $-0.15^{*}$ & -0.12 & $-0.24^{* *}$ & -0.12 & $-0.15^{*}$ & 0.01 & $0.18^{*}$ \\
\hline
\end{tabular}

**, *: Significant at 1 and $5 \%$ probability, respectively, by the t-test.

Height of plant (HP-2014 and HP2015), canopy width (CW-2014 and LC-2015), diameter of stem (DC-2014 and DC-2015), number of branches (NB-2014 and NB-2015), length of leave (LL-2014 and LL-2015), width of leave (WL-2014 and WL-2015), fruit weight (FW), number of seeds (NS), diameter of fruit (DF), width of fruit (WF), and soluble solids (SS)

Tabela 2 - (continuation)

\begin{tabular}{lccllllll}
\hline & WL-2014 & WL-2015 & NB-2014 & NB-2015 & PFW & SS & NS & DF \\
\hline WL-2015 & $0.77^{* *}$ & & & & & & & \\
NB-2014 & $-0.17^{*}$ & $-0.19^{*}$ & & & & & & \\
NB-2015 & $-0.17^{*}$ & $-0.19^{*}$ & $1.00^{* *}$ & & & & & \\
FW & -0.02 & 0.08 & 0.10 & 0.10 & & & & \\
SS & 0.00 & -0.02 & 0.02 & 0.02 & $-0.16^{*}$ & & & \\
NS & 0.04 & 0.11 & 0.10 & 0.10 & $0.50^{* *}$ & -0.11 & & \\
DF & 0.01 & 0.11 & 0.10 & 0.10 & $0.88^{* *}$ & $-0.18^{*}$ & $0.49^{* *}$ & \\
WF & -0.03 & 0.09 & 0.08 & 0.08 & $0.89^{* *}$ & $-0.18^{*}$ & $0.48^{* *}$ & $0.89^{* *}$ \\
\hline
\end{tabular}

**, *: Significant at 1 and $5 \%$ probability, respectively, by the t-test.

Width of leave (WL-2014 and WL-2015), fruit weight (FW), number of seeds(NS), diameter of fruit (DF), width of fruit (WF), and soluble solids (SS).

The traits evaluated presented the greatest magnitudes of correlation, being for the most part significant and positive, indicating that the selection of genotypes that present a better development may bring gains to future works on improvement. In contrast, the characteristics of the plant showed little significant correlation with the characteristics of the fruit. 
Fruit weight (FW) had the highest significant correlations among the characteristics of fruits, being the main ones NS (0.50), DF (0.88) and WL (0.89).

Soluble solids content was considered an important fruit flavor quality factor. This study showed that soluble solids content showed a significant positive correlation with CW-2015 (0.21) and DS-2015 (0.19) and a negative correlation with NS (-0.11), FW (-0.16) and DF $(-0.18)$. Even if soluble solids content is used as a palatability reference, care should be taken when selecting genotypes based on this characteristic alone in plant breeding, as it is correlated with other characteristics, and may have an undesirable indirect effect. One of the characteristics negatively correlated with soluble solids content is number of seeds which, with their reduction, may favor the increase in soluble solids and decrease fruit weight. Pelloso (2011) also reported a negative correlation between soluble solids and fruit size.

The study of correlations between a characteristic of high agronomic relevance serves as a basis for guiding the selection or disposal of variables during genetic improvement. However, one must con- sider the possibility of selecting one characteristic to obtain a response in another (Pinto et al., 2010), which may select indirectly plants with fruits of a higher mass, evaluating only the diameter of fruits in the field, without weighing them (Camilo et al., 2014).

By this, the determination of a correlation between the characteristics related to the production and other agronomic traits is of paramount importance. This information important to evaluate how much changes in one trait may affect another trait (Oliveira et al. 2010) during improvement stages (Cruz et al., 2004), because it allows the definition of strategies over time to a breeding program and, in this case to perennial plants, such as Gabirobeira, that may facilitate selection in auxiliary characters that can be measured at early stages.

Based on Tocher cluster analysis (Table 3), 18 groups can be identified. This result demonstrates that the studied genotypes have a variability to be worked on in future improvement programs and contribute, as a genetic resource, to the maintenance of variability in the species.

Table 3 - Grouping by the Tocher optimization method for the 173 accesses studied, using the mean euclidean distance matrix.

\begin{tabular}{ll}
\hline Groups & \multicolumn{1}{c}{ Genotypes } \\
\hline I & 355213836715714110038102113512290275533320232649777115816135 \\
II & 28451667310712061111491564136 \\
III & 145172256512144140122809413471158123137147112 \\
IV & 34668517010544124114 \\
V & 601428712514350 \\
VI & 5459 \\
VII & 69162106 \\
VIII & 86118161 \\
IX & 121167169101 \\
X & 4255 \\
XI & 92154 \\
XII & 1529 \\
XIII & 56 \\
XIV & 48 \\
XV & 40 \\
XVI & 171 \\
XVII & 103 \\
XVIII & 24 \\
\hline
\end{tabular}

For the grouping by UPGMA (Figure 1), a cutoff point was obtained in the dendrogram at a distance of 19.25 , which corresponds to $40.58 \%$ of the distance between the genotypes studied. Based on this cut-off point, 18 groups were formed. It can be observed that the formation of these groups is adequate because the co-phenetic correlation (CCC) is equal to $76 \%$. According to Cruz \& Carneiro (2012), the CCC evaluates the fit between dissimilarity and simplification matrices, and can be used as a reliability criterion for the interpretations of hierarchical grouping methods (UPGMA).
By analyzing the results in a joint way, it can be seen that the formation of 18 groups for both grouping methods was consistent and, in general, the groupings were composed by the same genotypes in both methods. This confirms the existence of dissimilarity between the materials studied, which indicates a good representation in terms of conservation of genetic resources and possibilities to select individuals with adequate performance to be worked on by productive systems. 


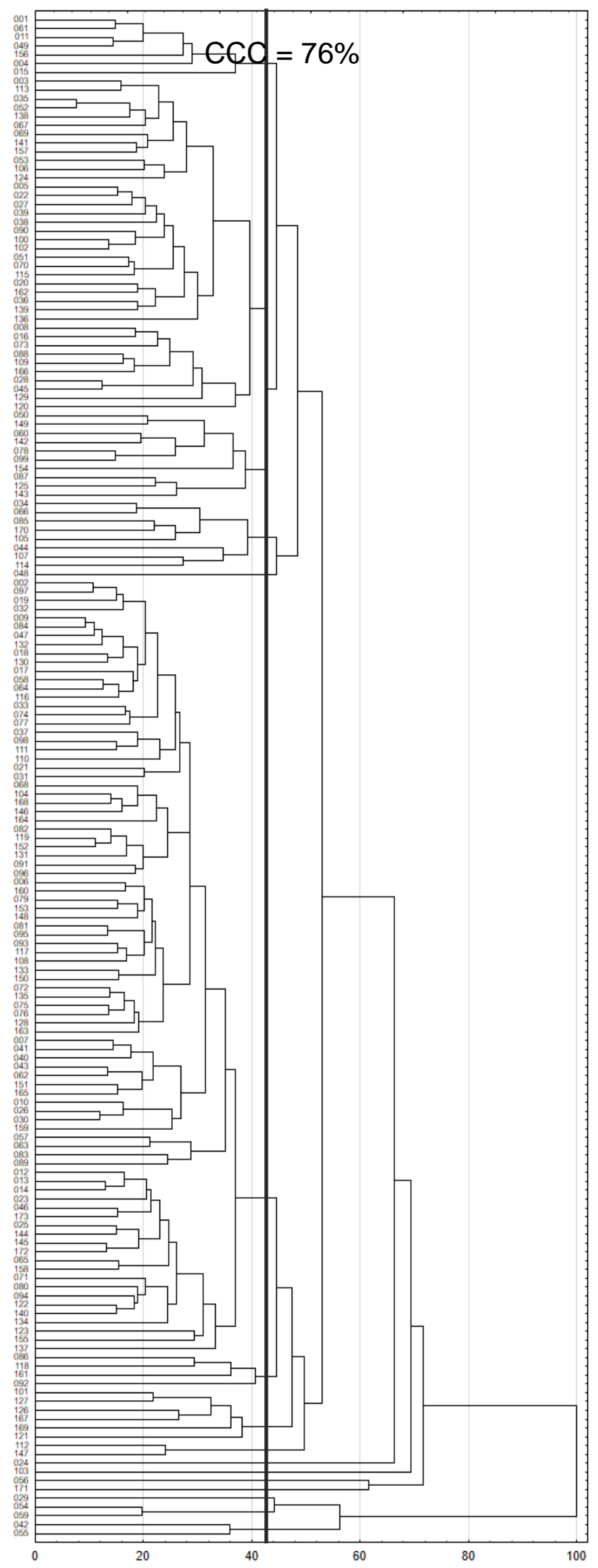

Figure 1 - Dendrogram of dissimilarity among the 173 accessions studied based on the morphological characteristics evaluated. The dotted vertical line corresponds to the cut-off point in the dendrogram. 


\section{Conclusion}

The results evidence that there is a genetic variability based on the morphological traits of plants and fruits in the germplasm bank, which can be used as a guide for its maintenance and also to explore this variability in future genetic improvement works.

\section{References}

Alves AM, Alves MSO, Fernandes TO, Naves RV, Naves MMV (2013) Caracterização física e química, fenólicos totais e atividade antioxidante da polpa e resíduo de gabiroba. Revista Brasileira de Fruticultura 35(3):837-844.

Amaral EVEJ, Reis EF, Ressel K, Pinto JFN (2016) Descrição morfológica de duas espécies de Campomanesia Ruiz \& Pavon (Myrtaceae), Revista Agrotecnologia 7(1):42-52.

Assis ES, Reis EF, Pinto JFN, Contim LAS, Dias LAS (2013). Genetic diversity of gabiroba based on random amplified polymorphic DNA markers and morphological characteristics. Genet. Mol. Res, 12:3500-3509.

Camilo YMC, Souza ERB, Vera R, Naves RV (2014) Caracterização de frutos e seleção de progênies de cagaiteiras (Eugenia dysenterica DC.). Científica, Jaoticabal, 42(1):1-10.

Clement CR (2001) Melhoramento de espécies nativas. In: Nass LL, Valois ACC, Melo IS, ValadaresIngles MC (Ed.) Recursos genéticos \& melhoramento plantas. I ed. Rondonópolis: Fundação de Apoio à Pesquisa Agropecuária de Mato Grosso - Fundação MT. p.423-441.

Costa TS, Silva AVC, Lédo AS, Santos ARF, SilvaJúnior JF (2011) Diversidade genética de acessos do banco de germoplasma de mangaba em Sergipe. Pesquisa Agropecuária Brasileira 46(5):499-507.

Coutinho ID, Kataoka VMF, Honda NK, Coelho RG, Vieira MC, Cardoso CAL (2010) Influência da variação sazonal nos teores de flavonóides e atividade antioxidante das folhas de Campomanesia adamantium (Cambess.) O. Berg, Myrtaceae. Rev. Bras. Farmacogn 20(3):322-327.

Cruz CD (2016) Genes Software - extended and integrated with the $R$, Matlab and Selegen. Acta Scientiarum. Agronomy, 38:547-552.

Cruz CD, Carneiro PCS (2012) Modelos biométricos aplicados ao melhoramento genético. 4.ed. Viçosa: UFV, 514p.

Cruz CD, Ferreira FM, Pessoni LA (2011) Biometria aplicada ao estudo da diversidade genética. Visconde do Rio Branco, MG: Suprema, 620p.
Cruz CD, Regazzi AJ, Carneiro PCS (2004) Modelos biométricos aplicados ao melhoramento genético. 3.ed. Viçosa: UFV, 480p.

Dresch DM, Scalon SPQ, Masetto TE, Vieira MC (2013) Germinação e vigor de sementes de gabiroba em função do tamanho do fruto e semente. Pesquisa Agropecuária Tropical 43(3):262-271.

Freitas JB, Cândido TLN, Silva MR (2008) Geléiade Gabiroba: avaliação da aceitabilidade de características físicas e químicas. Pesquisa Agropecuária Tropical 38(2):87-94.

Garcia, CH (1989) Tabelas para classificação de coeficientes de variação. Piracicaba: IPEF, 12p. (Circular Técnica, 171)

Landrum LR (1982) The Development of the Fruits and Seeds of Campomanesia (Myrtaceae). Brittonia 34(2):220-224.

Lima DF, Goldenberg R, Sobral M (2011) O gênero Campomanesia ( Myrtaceae ) no estado do Paraná, Brasil. Rodriguésia-Instituto de Pesquisas Jardim Botânico do Rio de Janeiro 62(3):683-693.

Lima LL, Nunes GHS, Bezerra Neto F (2004) Coeficientes de variação de algumas características do meloeiro: uma proposta de classificação. Horticultura Brasileira, 22(1):14-17.

Lorenzi H, Bacher L, Lacerda M, Sartori S (2006) Frutas Brasileiras e Exoticas Cultivadas: de consumo in natura. Instituto Plantarum de Estudos da Flora. p.382.

Milligan GW, Cooper MC (1985) An examination of procedures for determining the number of clusters in a data set. Psychometrika, 50(2):159-179.

Mojena R (1977) Hierarchical grouping methods and stopping rules: an evaluation. The Computer Journal 20(4):359-363.

Morzelle MC, Bachiega P, Souza EC, Boa EVBV, Lamounier ML (2015) Caracterização química e física de frutos de Curriola, Gabiroba e Murici provenientes do Cerrado basileiro. Revista Brasileira de Fruticultura 37(1):96-103. Doi: 10.1590/0100-2945-036/14

Oliveira EJ, Lima DS, Lucena RS, Motta TB, Dantas JLL (2010) Correlações genéticas e análise de trilha para número de frutos comerciais por planta em mamoeiro. Pesq. agropec. bras., 45(8), 855-862.

Oliveira MC, Santana DG, Santos CM (2011) Biometria de frutos e sementes e emergência de plântulas de duas espécies frutíferas do gênero Campomanesia. Revista Brasileira de Fruticultura 33(2):446-455

Pavan FR, Leite CQF, Coelho RG, Coutinho ID, Honda NK, Cardoso CAL, Vilegas W, Leite SRA (2009) Evaluation of anti-Mycobacterium tuberculosis activity of Campomanesia adamantium (Myrtaceae). Química Nova 32(5):1222-1226. 
Pelloso IAO (2011) Caracterização fenotípica de frutos e desenvolvimento inicial de plantas de Campomanesia adamantium (CAMBESS) O. BERG, em Mato Grosso do Sul. Tese (Doutorado em Agronomia: Produção Vegetal) - Universidade Federal da Grande Dourados. 54p.

Pereira LD, Costa ML, Pinto JFN, Assunção HF, Reis EF, Silva DFP (2017). Propagação de Gabirobeiras via estaquia associada ao ácido indolbutírico. Revista Brasileira de Agropecuária Sustentável, 7(1):19-25.

Pinto JFN, Reis EFD, Faleiro FG, Barbosa ECC, Nunes HF, Pinto JFN (2010). Seleção de descritores vegetativos para caracterização de acessos de guariroba (Syagrus oleracea (Mart.) Becc.). Revista Brasileira de Fruticultura, Jaboticabal, 32(3):1-8.
Singh D (1981) The Relative Importance of Characters Affecting Genetic Divergence. The Indian Journal of Genetics and Plant Breeding 41(2):237-245.

Sudré CP, Rodrigues R, Riva EM, Karasawa M, Amaral Júnior AT (2005) Divergência genética entre acessos de pimenta e pimentão utilizando técnicas multivariadas. Horticultura Brasileira, 23(1):22-27.

StatSoft, Inc (1999) STATISTICA for Windows. StatSoft, Inc., Tulsa, Oklahoma.

Vieira RF, Costa TSA, Silva DB, Ferreira FR, Sano SM (2006) Frutas Nativas da região Centro-Oeste do Brasil. Embrapa Informação Tecnológica: Embrapa Recursos Genéticos e Biotecnologia. Brasília, DF. 